\title{
Highly Specific L-Type Amino Acid Transporter 1 Inhibition by JPH203 as a Potential Pan-Cancer Treatment
}

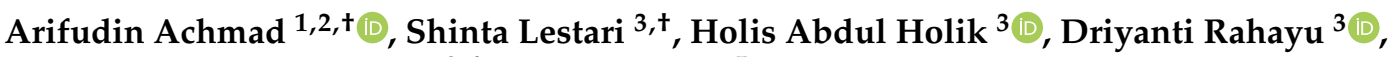 \\ Muhammad Hasan Bashari ${ }^{2,4}$, Ahmad Faried ${ }^{5}$ and Achmad Hussein Sundawa Kartamihardja ${ }^{1, *}$ \\ 1 Department of Nuclear Medicine and Molecular Theranostics, Faculty of Medicine, \\ Universitas Padjadjaran/Hasan Sadikin General Hospital, Bandung 40161, Indonesia; \\ a.achmad@unpad.ac.id \\ 2 Oncology and Stem Cell Working Group, Faculty of Medicine, Universitas Padjadjaran, \\ Bandung 40161, Indonesia; bashari@unpad.ac.id \\ 3 Department of Pharmaceutical Analysis and Medicinal Chemistry, Faculty of Pharmacy, \\ Universitas Padjadjaran, Sumedang 45363, Indonesia; shinta16002@mail.unpad.ac.id (S.L.); \\ holis@unpad.ac.id (H.A.H.); driyanti.rahayu@unpad.ac.id (D.R.) \\ 4 Division of Pharmacology and Therapy, Department of Basic Medical Sciences, Faculty of Medicine, \\ Universitas Padjadjaran, Bandung 40161, Indonesia \\ 5 Department of Neurosurgery, Faculty of Medicine, Universitas Padjadjaran/Hasan Sadikin General Hospital, \\ Bandung 40161, Indonesia; ahmad.faried@unpad.ac.id \\ * Correspondence: hussein2017@unpad.ac.id \\ + Equal contributions.
}

check for

updates

Citation: Achmad, A.; Lestari, S.; Holik, H.A.; Rahayu, D.; Bashari, M.H.; Faried, A.; Kartamihardja, A.H.S. Highly Specific L-Type Amino Acid Transporter 1 Inhibition by JPH203 as a Potential Pan-Cancer Treatment. Processes 2021, 9, 1170. https://doi.org/10.3390/pr9071170

Academic Editors: Zdenek Kejik and Michal Masarik

Received: 1 May 2021

Accepted: 2 July 2021

Published: 5 July 2021

Publisher's Note: MDPI stays neutral with regard to jurisdictional claims in published maps and institutional affiliations.

Copyright: (C) 2021 by the authors. Licensee MDPI, Basel, Switzerland. This article is an open access article distributed under the terms and conditions of the Creative Commons Attribution (CC BY) license (https:/ / creativecommons.org/licenses/by/ $4.0 /)$.
Abstract: Accelerated cancer cell growth requires a massive intake of amino acids. Overexpression of L-type (large) amino acid transporter 1 (LAT1) on the cancer cell membrane facilitates such a demand, which is limited in normal organs. Therefore, LAT1 overexpression is ideal as a molecular cancer therapeutic target. JPH203, a LAT1-selective non-transportable blocker, had demonstrated LAT1 inhibition in $<10 \mu \mathrm{M} \mathrm{IC}_{50}$ values and effectively suppressed cancer cell growth in studies involving several types of cancer cell lines and tumor xenograft models. A limited phase I clinical trial was performed on five different solid tumors and showed that JPH203 is well-tolerated and has a promising activity for the treatment of bile duct cancer. This review details the development and prospect of JPH203 as a LAT1-targeting cancer therapy.

Keywords: cancer; JPH203; LAT1; targeted drug; amino acid metabolism

\section{Introduction}

Global Cancer Incidence, Mortality and Prevalence (GLOBOCAN) data in 2018 reported 18.1 million new cases and 9.6 million cancer deaths [1], and this global burden remains increasing annually [2]. Cancer is characterized by uncontrolled cell growth and resistance to cell death as a result of the reprogramming of the energy metabolism and other survival hallmark capabilities [3]. Most of the currently used anticancer drugs are either nonselective for cancer cells or extend patients' survival only a few months.

Most chemotherapeutic agents are designed to disrupt the nucleic acid biosynthesis in rapidly developing cells [4]. Consequently, systemic chemotherapies are highly cytotoxic to the physiologically fast-growing normal cells resulting in detrimental side effects [5]. Various targeted drugs developed in the later decades were designed to work on specific molecular targets in cancer cells, thereby sparing non-target organs while retaining the therapeutic benefit [6]. However, even the most advanced targeted drugs available today, as monotherapy or in combinations to overcome tumor heterogeneity, are unable to prevent the subsequent development of drug resistance [7]. Obviously, new molecular targets are sorely needed to solve these complicated challenges of cancer treatment.

Cancer cells have independent metabolic regulation and almost always find a way to fuel their fast growth and expansion [8]. Glucose hypermetabolism (GLUT1 overexpression) 
has been long exploited as a cancer biomarker (as seen in widely accepted oncology $\left[{ }^{18} \mathrm{~F}\right]$ FDG PET imaging); however, it is not cancer-specific. Amino acid hypermetabolism, on the other hand, potentially serves as a better cancer biomarker in terms of tumorspecificity and less adverse effects to normal organs since no normal adult organs are physiologically amino acid-hypermetabolic [9]. L-type Amino acid Transporter 1 (LAT1), the main transporter of large neutral branched-chain amino acids, is overexpressed in malignancies to support the increased demand for bulk protein synthesis that underpins their enhanced cell proliferation and survival [10]. LAT1 inhibition has been validated in many studies to block amino acid intake resulting in tumor growth delay, indicating that LAT1 is a valid molecular target for cancer therapy [11,12]. This review summarizes the development of JPH203 (KYT-0353), the only LAT1-selective non-transportable blocker which currently passed a phase I clinical trial [13].

\section{Targeted Drugs and Targeting Abnormal Metabolism of Cancer}

Targeted drugs have passed multicenter clinical trials and been marketed in the last 20 years, with various drug classes (small molecules, peptides, proteins, antibodies) and also various molecular targets (generally cell signaling), ranging from angiogenesis (VEGF, VEGFR, $\alpha \mathrm{v} \beta 3$ integrin) and cell proliferation (EGFR, HER2) up to certain specific receptors (folic acid receptors, biotin D, LDL, CD20, etc.) [6,14]. However, their clinical application so far shows that achieving long-lasting therapeutic effects remains difficult due to subsequent drug resistance. Along with the increasing reports in cancer resistance against the cellsignaling-targeted drugs, roughly a decade ago, the targeted drug development led to immune checkpoint inhibitors (cancer immunotherapy) that engage the immune system to attack cancer cells [15]. Although initially promising, investigators began to report the rise of cancer resistance toward this new strategy [16]. When a particular signaling pathway is disrupted, cancer cells are capable of quickly adopting an escape mechanism by activating other pathways, thus developing resistance [17]. Therefore, an ideal molecular target not only should be highly cancer-specific (strictly available in cancer cells) but also have simultaneous catastrophic impacts toward several cancer hallmark pathways when disrupted.

The rapid proliferation of cancer cells demanding a high amount of energy and biomass material is depicted by the increased metabolic rate of glucose, lactate, pyruvate, hydroxybutyrate, acetate, glutamine, and fatty acids [8]. Blocking this metabolic upregulation seems rational as a therapeutic strategy. However, disrupting carbon metabolism (glucose and fatty acid metabolism) is a complicated task due to the interrelations between metabolic components. The dysregulation of the amino acid metabolism is another potential target. Apart from fulfilling high energy demands (via the tricarboxylic acid (TCA) cycle), the primary role of the amino acid metabolism is to secure biomass material supplies required for rapid cancer cell growth (nucleotides, proteins, and lipids) [8,18,19].

Even though excessive glucose consumption is prominent in proliferating cells including cancer, amino acids rather than glucose are responsible for the majority of cell carbon mass [20]. Amino acids in highly proliferating cells are employed in versatile ways as scaffold molecules for producing biomass, as various proteins for signaling purposes, and for fueling energy; all are centered in anaplerotic reactions in the TCA cycle [10]. In the TCA cycle, amino acids are involved in energy production, redox balance, cell invasion and metastasis, apoptosis, and activation of the mammalian target of rapamycin (mTOR) complex. Branched-chain amino acids (leucine, isoleucine, lysine, phenylalanine, tryptophan, and tyrosine) are among the main source of acetyl-CoA, the starting point of this cycle, as well as alanine, cysteine, glycine, serine, and threonine which are converted first into pyruvate. Glutamine, glutamate, leucine, aspartate, asparagine, methionine, and serine are among the top amino acids linked with cancers [10]. Leucine, in particular, is a quintessential amino acid not only as a building block but also responsible for activation of mTOR signaling resulting in cell death resistance and uncontrollable tumor growth $[10,21]$. Me- 
thionine is the methyl donor for DNA methylation, thus contributing to cancer epigenetics, protein synthesis, and survival [10].

A precondition for such increased demand of amino acids is the over-expression of the membrane transporters responsible for amino acid uptake from the cells' environment across the cell membrane. At least 61 types of amino acid transporters are known to be involved in physiological and pathological processes, divided into eight systems (system A, $\mathrm{N}, \mathrm{ASC}, \mathrm{B}, \mathrm{L}, \mathrm{T}, \mathrm{x}^{-}{ }_{\mathrm{c}}$, and $\mathrm{y}^{+}$) based on their transport mechanism and substrate specificity. However, only a few are involved in malignancy including AlaSerCys (alanine-serinecysteine) transporter 2 (ASCT2), LAT1, $\mathrm{ATB}^{0,+}$, and SNAT2 [19]. Both ASCT2 and LAT1 expression have been associated with several hallmarks of cancer, e.g., avoiding immune destruction, activating invasion and metastasis, inducing angiogenesis, resisting cell death, sustaining proliferative signaling, and dysregulating cellular energetics [12]. These unique features have been inspiring researchers to establish ASCT2 and LAT1 as novel targets for tumor-specific delivery of appropriately designed chemotherapeutic drugs [22]. However, since ASCT2 is also expressed in several normal adult organs and also in inflammation, currently LAT1 is the only amino acid transporter with true potential as a highly tumorspecific molecular target for therapy [19].

\section{LAT1}

LAT1 (SLC7A5) is a transmembrane protein member of the L system transporter subfamily (along with LAT2, LAT3, and LAT4) of the SLC7 family of amino acid transporters which transports large, neutral (or with branched) amino acids [19,21]. LAT1 forms heterodimers with the 4F2hc (SLC3A2) subunit as a LAT1/CD98 complex (Figure 1). The $4 \mathrm{~F} 2 \mathrm{hc}$ subunit is not directly involved in the transport mechanism but provides stability for the complex at the cell membrane, essential for the LAT1 transport activity $[11,21,23,24]$.

A. His lle Met

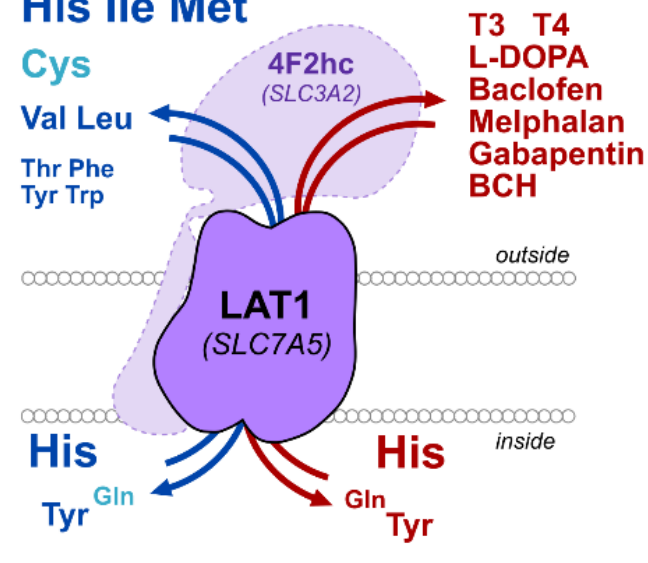

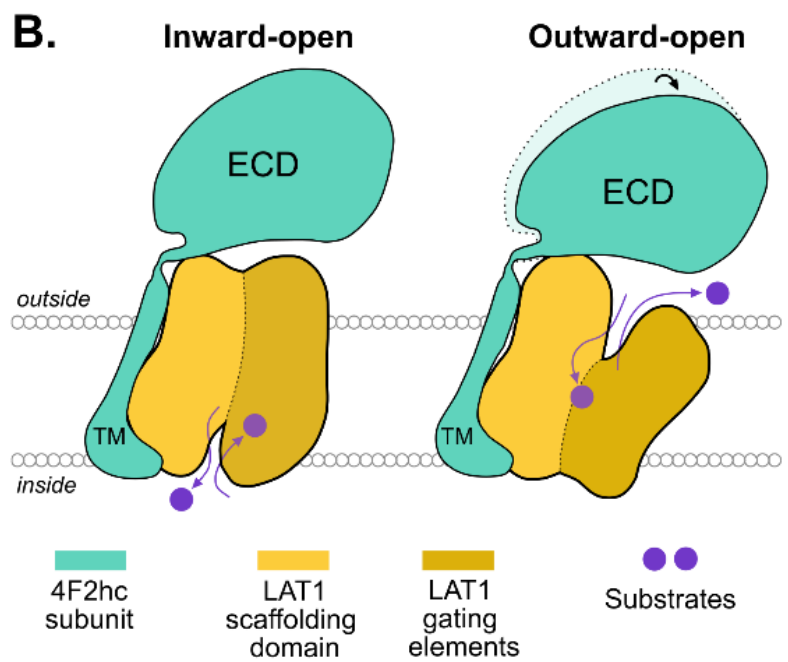

Figure 1. (A) LAT1/CD98 (4F2hc) complex schematic structure and its transport function. Blue represents essential amino acids and light blue represents non-essential amino acids (the size indicates the level of specificity of LAT1 to amino acids). The red color represents specificity for non-amino acid substrates (hormones, drugs, inhibitors) [21]. (B) LAT1/CD98 (4F2hc) complex working mechanism model. ECD: extracellular domain, TM: transmembrane domain [24].

LAT1 is the primary transporter of essential amino acids in the placenta and BloodBrain Barrier (BBB) [21]. The LAT1 substrate and its transport preference are as follows: phenylalanine $>$ tryptophan $>$ leucine $>$ isoleucine $>$ methionine $>$ histidine $>$ tyrosine $>$ valine. LAT1 also transports several types of drugs similar to amino acids such as LDOPA, melphalan, baclofen, $\mathrm{BCH}$ (2-Amino-2-norbornene carboxylic acid), gabapentin, and thyroid hormones triiodothyronine (T3) and tetraiodothyronine/thyroxine (T4) [11,23]. 
LAT1 is upregulated in all human cancers [10], including glioma, breast cancer, pancreas, stomach, esophagus, tongue, hypopharynx, larynx, lung, hepatocellular carcinoma, ovarian cancer, and renal cell carcinoma [25-37]. The very low LAT1 expression in normal cells (only expressed in the BBB epithelial cells, placenta, monocytes, macrophages, testis, and pancreatic $\beta$ cells) makes LAT1 an ideal cancer molecular target for therapy [21]. LAT1 has long been the target of diagnostic oncology imaging using the positron emission tomography (PET) radiopharmaceutical $3-\left[{ }^{18} \mathrm{~F}\right]$-fluoro-L- $\alpha$-methyl tyrosine $\left(\left[{ }^{18} \mathrm{~F}\right]-\mathrm{FAMT}\right)$, a LAT1-specific substrate [38,39]. Although the LAT1 specificity of FAMT has been elucidated [40], the development of $\left[{ }^{18} \mathrm{~F}\right]$-FAMT-alike (small) substrate-based therapeutic targeted drugs will not be of much use because of the two-way LAT1 transport properties (one amino acid influx is always exchanged for one amino acid efflux out of the cell). Moreover, the LAT1 affinity toward intracellular substrates is higher than for extracellular substrates, indicating that the rate of substrate transport is controlled by intracellular substrate concentrations. Thus, the rational design of LAT1-targeting drugs requires the following: (1) LAT1-specific, (2) non-transportable blockers/inhibitors, and (3) competitive with high affinity [23].

More than a hundred LAT1 inhibitors have been reported, and most of them are amino acid derivatives. However, only a few of these blockers are potent and selective, including JPH203, a tyrosine/T3-derived amino acid developed by a group of researchers in Japan [23]. In 2002, the basic concept of LAT1 targeting was described, including small aromatic amino acids requiring free carboxyl groups and amine groups [41]. Since then, various selective LAT1 compounds have been synthesized.

\section{JPH203}

In 2008, Endou et al. successfully synthesized and patented KYT-0353 (JPH203, IUPAC name: (2S)-2-amino-3-[4-[(5-amino-2-phenyl-1,3-benzoxazole-7-yl)methoxy]-3,5dichlorophenyl] propanoic acid; $\mathrm{C}_{23} \mathrm{H}_{19} \mathrm{C}_{12} \mathrm{~N}_{3} \mathrm{O}_{4}$; molecular weight $472.3 \mathrm{~g} / \mathrm{mol}$ ), a tyrosine analogue features strong and selective inhibition to LAT1 (Figure 2) [42].

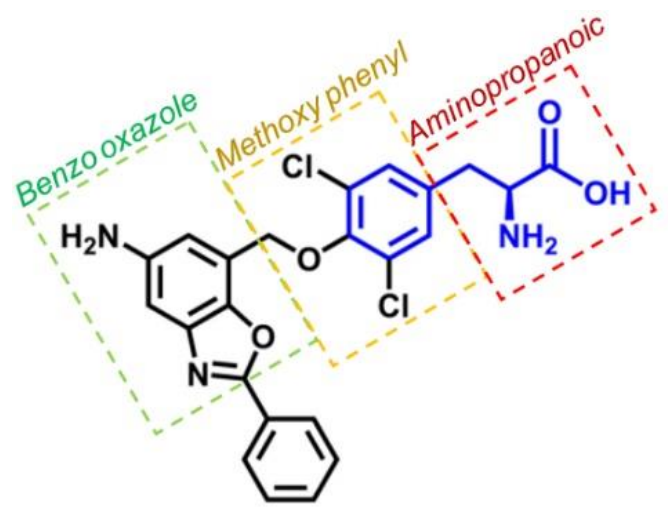

JPH203 (KYT-3035)<smiles>N[C@@H](Cc1cc(I)c(Oc2ccc(O)c(I)c2)c(I)c1)C(=O)O</smiles>

Triiodothyronine (T3)<smiles>N[C@@H](Cc1cc(I)c(Oc2cc(I)c(O)c(I)c2)c(I)c1)C(=O)O</smiles>

Tetraiodothyronine (T4)

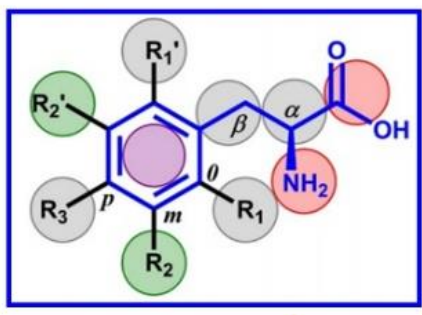<smiles>N[C@@H](Cc1ccccc1)C(=O)O</smiles>

Phenylalanine

Figure 2. The structure of JPH203, T3, T4, and phenylalanine. The same group is marked in blue. The JPH203 framework consists of three basic parts [43]. Blue box: The structure-activity relationship (SAR) from the L-phenylalanine. The positions of the two $\alpha$-amine and $\alpha$-carboxyl (red circle) groups are held sterically. The position of the aliphatic portion of the side chain marked $\alpha$ and $\beta$ (gray circle) is tolerating modifications. The aromatic rings of the side chains are marked with a purple circle and their positions include ortho $\left(0, \mathrm{R} 1\right.$, and $\left.\mathrm{R} 1^{\prime}\right)$, meta $\left(m, \mathrm{R} 2\right.$, and $\left.\mathrm{R} 2{ }^{\prime}\right)$, and para $(p, \mathrm{R} 3)$. All positions in the aromatic chain can tolerate modification and steric mass, but meta positions are important for affinity [44].

JPH203 was designed based on inhibition of ${ }^{14} \mathrm{C}$-phenylalanine influx and efflux (e.g., melphalan, T3, and T4), the only known characteristics of LAT1 inhibitors and 
substrates. At that time (in the early 2000s), in vitro data suggested that to be an active LAT1 substrate/ligand, a compound should have a free amino acid moiety (aminopropanoic group) and a hydrophobic side chain (blue structure in Figure 2) [45]. Not surprisingly, "2Amino-3-phenylpropanoic acid" (L-phenylalanine) was widely used as a prototype ligand to evaluate LAT1 transport activity. Structure-Activity relationships (SAR) of phenylalaninebased LAT1 ligands showed that if affinity is to be retained, modifications can only be made on the aromatic ring $\left(\mathrm{R}_{1-3}\right)$ [44]. For that reason, the JPH203 synthesis route (Figure 3) shows an attempt to keep the aminopropanoic group intact [42]. In brief, JPH203 is obtained from the conjugation of compound 10 and compound 13. Compound 10, the bulk side chain of the final structure, is synthesized from a commercially available 3-nitro salicylic acid with a series of protection and deprotection reactions. Compound 13, the primary aromatic ring in the final structure, is obtained by chlorination of a commercially available methyl tyrosinate (compound 11) followed by Boc protection of the amine group. Following the conjugation step, the JPH203 is obtained after reducing the nitro group and removing Boc and the methyl protecting group.

In 2002, an experimental and semiempirical computational analysis proposed a model for the substrate-binding site of LAT1 and showed that to be a LAT1 substrate, a small aromatic amino acid must have: (1) a free carboxyl group, (2) an amino group with a nitrogen charge of $\sim-0.27$, and (3) carbonyl oxygen close to the amino group with a charge of $-0.55 \sim-0.56$ which does not participate in hydrogen bonding. A LAT1 substrate will be a selective non-transportable LAT1 inhibitor if Connolly accessible areas are large enough $\left(>500 \AA^{2}\right)$ and/or it has a ClogP $>2.0$. This study also revealed that the hydrophobic interaction between the substrate side chain and the substrate-binding site of LAT1 is crucial for substrate binding. All of these requirements were fulfilled by T3 [45]. A recent study showed that halogen substituents ( $\mathrm{Cl}$ or I) on the meta position of the aromatic ring as seen on T3 and T4 is important for binding affinity as they may modulate lipophilicity and participate in polar interactions [44].

A retrospective quantitative SAR study of LAT1 binding (Figure 4) recently revealed the key different characteristics between a LAT1 substrate (Figure 4, below the red dotted lines) and a LAT1 inhibitor (Figure 4, all, in this example, JPH203) at the substrate-inhibitor binding pocket interface (Figure 4, C and D), including: (1) LAT1 binding requires an amino acid functionality (Figure 4, A); (2) LAT1 may tolerate a methyl group at the $\alpha$-carbon (Figure 4, B); (3) amino acid L-stereochemistry is preferred (Figure 4, B); (4) LAT1 prefers aromatic amino acids (e.g., tyrosine, phenylalanine); (5) size/electronic effects as small as $\sim 5 \AA$ away from the $\alpha$-carbon may affect substrate/inhibitor properties (Figure $4, C$ ), (6) LAT1 may tolerate minor modifications such as $-\mathrm{NHCOMe},-\mathrm{NHMe},-\mathrm{NMe}_{2},-\mathrm{F}$, or $-\mathrm{CF}$ even though $-\mathrm{NH}_{2}$ is more preferred, and change in this part may have profound changes in inhibitory potency (Figure 4, E); (7) the nitrogen atom is important (Figure 4, F); and (8) the phenyl ring (Figure 4, G) should not be electronically distorted with a hydrogen-bonding group (inhibitory potency and/or LAT1:LAT2 selectivity may significantly change) [46].

Further efforts to search compounds better than JPH203 were based on LAT1 ligand/substrate SAR studies, in many cases using T3, a selective non-transportable LAT1 blocker, as the main structure and later optimized for selectivity and affinity [11,19]. Kongpracha et al. have tried to modify the intramolecular distance and angle to explore the other possibility of novel LAT1 blockers based on the T3 structure yielded in SKN series compounds. However, they found that the development of JPH203 might be already on the right track since the SKN series could not demonstrate any better affinity to LAT1 than JPH203. They conclude that the JPH203 hydrophobic side chains (methoxyphenyl and benzo oxazole) played an important role in the affinity toward the LAT1 binding site but with different molecular configurations from T3 (Figure 2) [43]. 

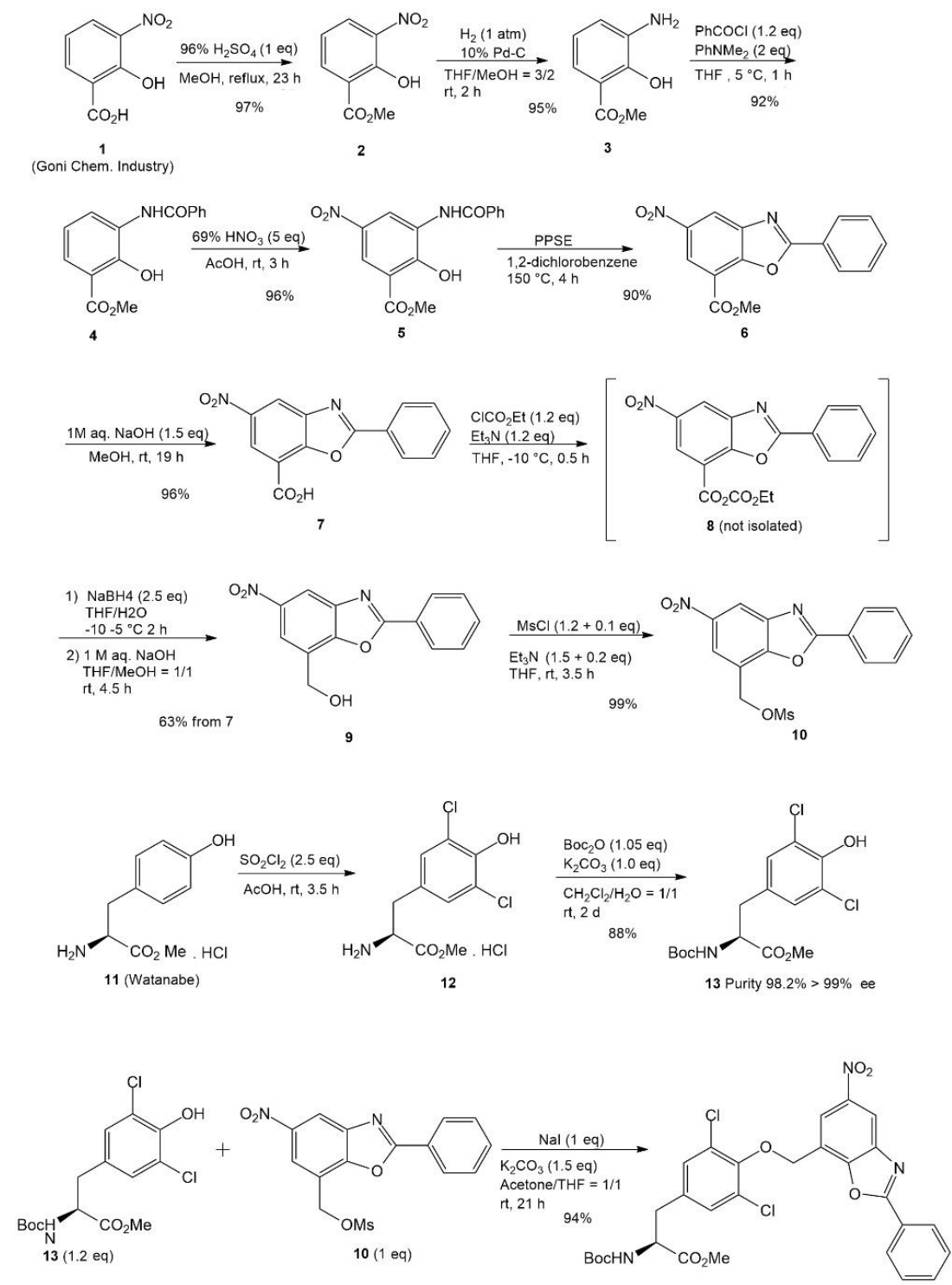

14 Purity $96.4 \%>99 \%$ ee

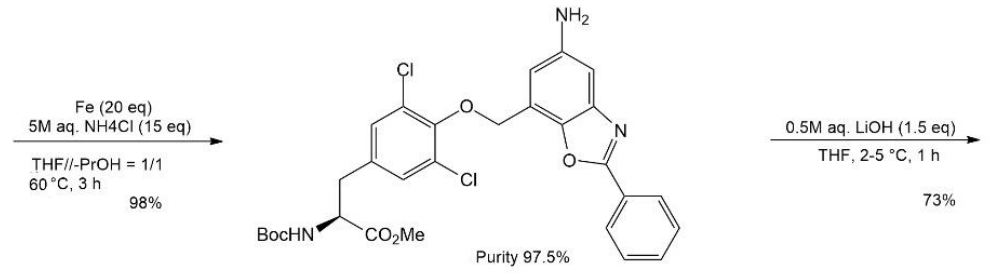

15
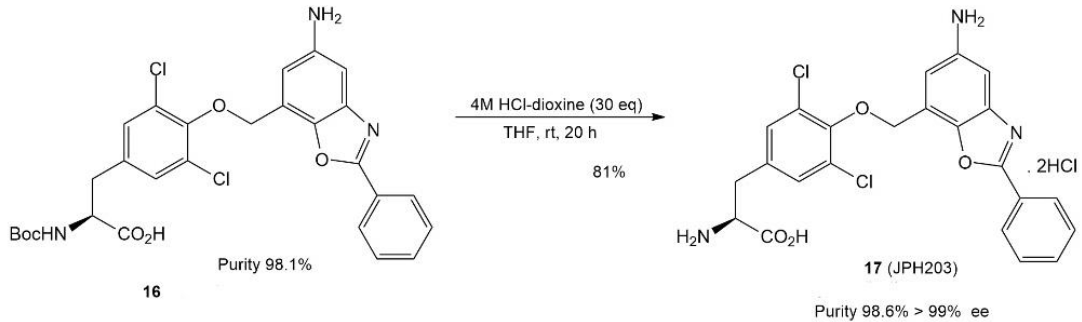

Figure 3. JPH203 synthesis pathway shows protection in aminopropanoic groups [42]. 


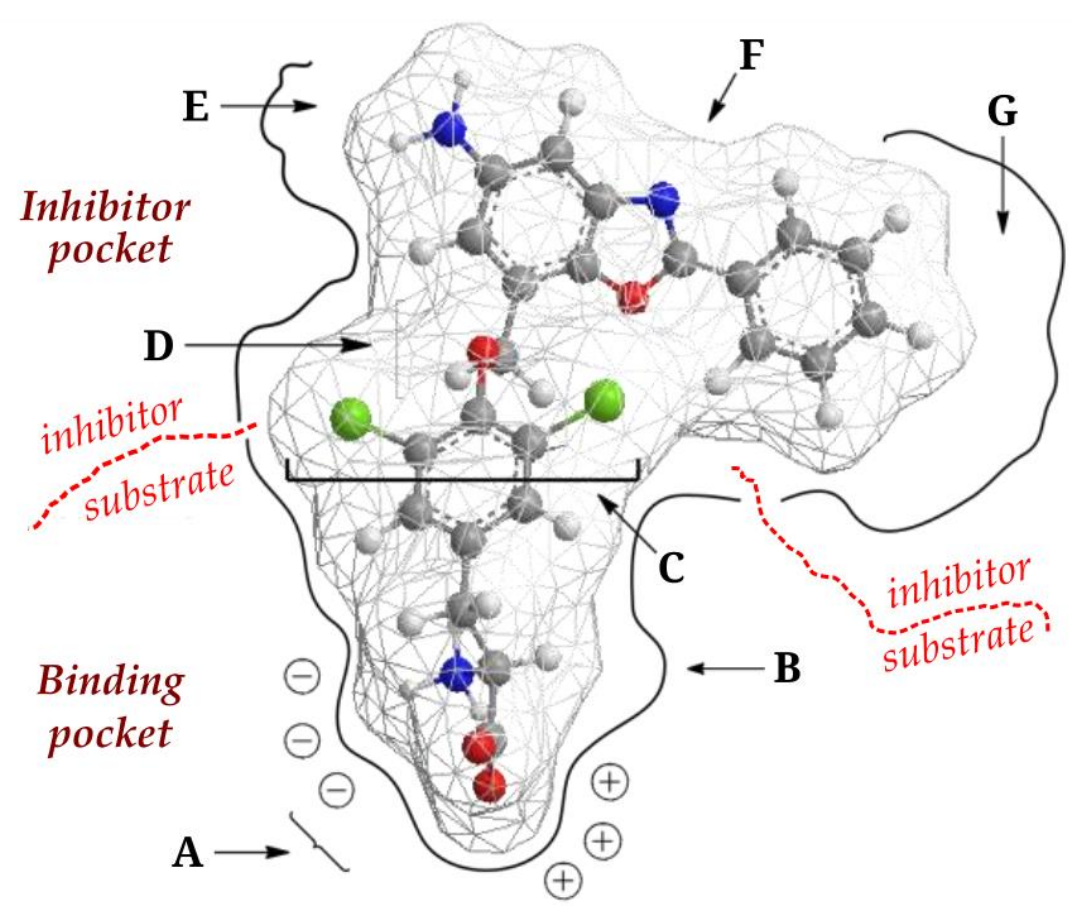

Figure 4. A model structure of a potent LAT1 inhibitor (JPH203) at the LAT1 binding pocket and its key characteristics to be a LAT1 substrate (A-C) or a LAT1 inhibitor (all) [46]. Legends: Regions: A. amino acid moiety; B. $\alpha$-carbon, C. aromatic ring with halogen substituents (green balls) on meta positions; C. and D. "substrate-inhibitor interface"; E. amine group on benzoxazole ring; F. nitrogen atom of benzoxazole ring; and G. phenyl ring. Atoms: grey (carbon), white (hydrogen), red (oxygen), blue (nitrogen), and green (halogen, as $\mathrm{Cl}$ or I).

The LAT1-inhibition mechanism of JPH203 has been previously studied computationally, and it was found that JPH203 has a more potent inhibitory effect than any large, neutral amino acids, L-DOPA, or BCH. However, due to its low solubility (highly hydrophobic), the details of the inhibiting mechanism could not be further investigated through cryo-electron microscopy [24]. In vivo studies show, after intravenous administration, that JPH203 is trapped by organic anion transporters into the liver cells and acetylated by the $\mathrm{N}$-acetyltransferase 2 (NAT2) enzyme into $\mathrm{N}$-acetyl-JPH203 (Nac-JPH203) before finally being passively excreted through the bile [41].

Although the detailed LAT1-inhibition mechanism remains unknown, in vitro and in vivo cancer studies on JPH203 continued. In 2010, Endou et al. published their first in vitro and in vivo proofs that JPH203 competitively inhibits ${ }^{14} \mathrm{C}$-leucine uptake $\left(\mathrm{IC}_{50} 0.06 \mu \mathrm{M}\right.$ ), inhibits HT-29 colorectal cancer cell proliferation ( $\left.\mathrm{IC}_{50} 4.1 \mu \mathrm{M}\right)$, and inhibits tumor growth in colorectal cancer models $\left(\mathrm{IC}_{50} 16.4 \mu \mathrm{M}\right)$ in nude mice xenografts [47]. Since then, JPH203 has been challenged against various types of cancer cells and implanted tumors on animal models.

In a recent study, LAT1 inhibition by JPH203 was reported to result in a global protein expression and phosphorylation which have a broad impact not only on the common biological pathways and signaling cascades but also several key pathways inducing the growth arrests. These proteomic and phosphoproteomic findings support the hypothesis that selective and efficient LAT1 inhibition would damage several cancer hallmarks simultaneously [48].

A structure-based study that combines homology modeling (based on the atomic structures of the prokaryotic homologs) with other computational methods has been able to screen 1.1 million molecules virtually to search potent LAT1 inhibitors in absence of an experimental 3D structure of LAT1. Two of the retrieved compounds (compound 36 and 42; both showed conserved polar interactions of the $\alpha$-amino and $\alpha$-carboxyl group) 
demonstrated complete and robust LAT1 inhibition with $\mathrm{IC}_{50}$ values of $0.64 \pm 0.12 \mu \mathrm{M}$ and $1.48 \pm 0.27 \mu \mathrm{M}$ [49]. However, since no further in vitro nor in vivo studies have been performed to validate these two compounds, JPH203 remains the most advanced LAT1 inhibitor currently available.

\section{In Vitro and In Vivo JPH203 Studies}

LAT1 is expressed in all cancer types; thus, no particular type of cancer is more important than others (regarding LAT1 expression) to be selected for evaluation of JPH203 inhibitory efficacy in preclinical studies. The methods of in vitro JPH203 studies are generally following these stages:

1. Cell culture in suitable media $\left(37^{\circ} \mathrm{C}\right.$ incubation in $95 \%$ air and $5 \% \mathrm{CO}_{2}$ atmosphere);

2. LAT1 and $4 \mathrm{~F} 2 \mathrm{hc} / \mathrm{CD} 98$ protein subunit expression analysis using immunohistochemistry, quantitative polymerase chain reaction (qPCR) or quantitative reverse transcription-polymerase chain reaction (qRT-PCR), and confirmed by a Western blot study;

3. Cell viability study;

4. L-leucine competitive uptake study; and

5. Cell growth inhibition study.

In in vivo studies, JPH203 was the main drug for therapeutic, pharmacodynamic, and pharmacokinetic evaluation in tumor xenograft small animal models. In the following passages, in vitro and in vivo studies involving JPH203 are described based on cancer types (Tables 1 and 2).

\subsection{Oral Cancer}

JPH203 was tested to inhibit the growth of YD-38, a human oral cancer cell line expressing LAT1, but not LAT2. JPH203 competitively inhibited the L-leucine uptake by YD-38 cells while inhibiting its growth. JPH203 is also controlling the YD-38 cell population via activation of apoptotic factors, including caspase and PARP. This study shows that the LAT1-inhibition by JPH203 on YD-38 cells induces apoptosis by suppressing the intracellular neutral amino acids level that is essential for growth [50].

Table 1. In vitro studies.

\begin{tabular}{|c|c|c|c|}
\hline Cancer Type [Ref] & Cell Type & LAT1 Expression & JPH203 Activities \\
\hline Bladder [27] & Cell T24 and 5637 & $\begin{array}{l}\text { LAT1 expression was significantly } \\
\text { higher in cancerous tissue than in } \\
\text { the surrounding normal tissue } \\
(p=0.0051) \text {. LAT } 1 \text { cell expression } \\
5637 \text { is higher than T } 24 \text { cells. }\end{array}$ & $\begin{array}{l}\text { Inhibit the proliferation of T24 } \\
\text { and } 5637 \text { cells with increasing } \\
\text { concentration }(20 \mu \mathrm{M}) \text {. }\end{array}$ \\
\hline Anaplastic thyroid [51] & $\begin{array}{l}3 \text { human ATC cells: cell 8505C, } \\
\text { OCUT-2, OCUT-6 }\end{array}$ & $\begin{array}{l}\text { LAT1 immunoreactivity was } \\
\text { detected in anaplastic thyroid } \\
\text { cancer tissue ( } 78 \%: 11 / 14 \text { cases) }\end{array}$ & $\begin{array}{l}\text { Inhibit } 87.0 \% \text { in } 8505 \mathrm{C} \text { cells, } 78.6 \% \\
\text { in OCUT- } 2 \text { cells, and } 75.0 \% \text { in } \\
\text { OCUT- } 6 \text { cells. }\end{array}$ \\
\hline Differentiated thyroid cancer [52] & $\begin{array}{l}\text { Papillary thyroid cancer cells: K1, } \\
\text { KTC, TPC-1; ATC cells: Hth104, } \\
\text { SW1736, 8505C }\end{array}$ & $\begin{array}{l}\text { LAT1 was expressed in } 6 \text { thyroid } \\
\text { cancer cells tested. }\end{array}$ & $\begin{array}{l}\text { Block LAT1 and reduce the } \\
\text { proliferation of } 5 \text { of } 6 \text { thyroid } \\
\text { cancer cells (relative IC } 50 \text { from } \\
1.3 \mu \mathrm{M} \text { to } 6.8 \mu \mathrm{M}) \text {. PTC cells are } \\
\text { less sensitive than } \mathrm{K} 1(16.9 \mu \mathrm{M}) \text {. }\end{array}$ \\
\hline Renal cells carcinoma [27] & Caki- 1 cells and ACHN & $\begin{array}{l}\text { LAT1 expression of } 97.8 \% \\
\text { ( } 90 / 92 \text { cases) }\end{array}$ & $\begin{array}{l}\text { Reduce cell viability by } \mathrm{IC}_{50} \\
\text { values of Caki-1 cells and ACHN } \\
\text { of } 2.5 \text { and } 2.7 \mu \mathrm{M} \text {, respectively. }\end{array}$ \\
\hline Medulloblastoma (MB) [53] & $\begin{array}{l}\text { Medulloblastoma cells are } \\
\text { independent of subgroup } 3 \\
\text { (HD-MB03) and Shh (DAOY) }\end{array}$ & $\begin{array}{l}\text { LAT1 expression was significantly } \\
\text { higher in cancerous tissue than in } \\
\text { adjacent normal tissue. }\end{array}$ & $\begin{array}{l}\text { Interfere with amino acid } \\
\text { homeostasis, mTORC1 activity, } \\
\text { proliferation, and survival of } \\
\text { medulloblastoma cells. }\end{array}$ \\
\hline Stomach [54] & MKN1 and MKN45 & $\begin{array}{l}\text { LAT1 was expressed in MKN1 } \\
\text { and MKN45 cells. }\end{array}$ & $\begin{array}{l}\text { Reduce cancer cells growth }\left(\mathrm{IC}_{50}\right. \\
41.7 \pm 2.3 \mu \mathrm{M} \text { in MKN1 cells and } \\
4.6 \pm 1.0 \mu \mathrm{M} \text { in MKN45 cells). }\end{array}$ \\
\hline
\end{tabular}


Table 1. Cont.

\begin{tabular}{|c|c|c|c|}
\hline Cancer Type [Ref] & Cell Type & LAT1 Expression & JPH203 Activities \\
\hline Colorectal [54] & LoVo and HT-29 & $\begin{array}{l}\text { LAT1 was expressed in LoVo and } \\
\text { HT29 cells. }\end{array}$ & $\begin{array}{l}\text { Reduce cancer cells growth }\left(\mathrm{IC}_{50}\right. \\
2.3 \pm 0.3 \mu \mathrm{M} \text { on LoVo and } \\
30.0 \pm 6.4 \mu \mathrm{M} \text { on HT29 cells })\end{array}$ \\
\hline Colorectal [47] & HT-29 & $\begin{array}{l}\text { LAT1 was expressed in } \\
\text { HT-29 cells. }\end{array}$ & $\begin{array}{l}\text { Inhibit }{ }^{14} \mathrm{C} \text {-leucine uptake and } \\
\text { cell growth }\left(\mathrm{IC}_{50} 0.06 \mu \mathrm{M} \text { and }\right. \\
4.1 \mu \mathrm{M} \text {, respectively). }\end{array}$ \\
\hline Bone (osteosarcoma) [55] & $\begin{array}{l}\text { Human osteosarcoma cells Saos } 2 \\
\text { and human osteoblastic cells }\end{array}$ & $\begin{array}{l}\text { LAT1 was detected and weakly } \\
\text { expressed in Saos } 2 \text { and FOB cells. }\end{array}$ & $\begin{array}{l}\text { Antiproliferative effects (on Saos2 } \\
\text { cells, } \mathrm{IC}_{50} 1 \text { st day } 4.09 \pm 0.53 \mu \mathrm{M} \\
\text { and } 4 \text { th day } 0.09 \pm 0.01 \mu \mathrm{M} \text {; on } \\
\text { FOB cells, } \mathrm{IC}_{50} 1 \text { st day } \\
24.1 \pm 4.1 \mu \mathrm{M} \text { and } 4 \text { th day } \\
2.8 \pm 0.3 \mu \mathrm{M} \text {. }\end{array}$ \\
\hline $\begin{array}{l}\text { Biliary Duct } \\
\text { (cholangiocarcinoma) [56] }\end{array}$ & $\begin{array}{l}\text { KKU-055, KKU-213, and } \\
\text { KKU-100. }\end{array}$ & $\begin{array}{l}\text { LAT1 was detected in all cells } \\
\text { studied and was the main } \\
\text { transporter of } \\
\text { cholangiocarcinoma cells }\end{array}$ & $\begin{array}{l}\mathrm{IC}_{50} \text { values (mean } \pm \mathrm{SD} \text { ) for } \\
\text { leucine uptake inhibition: } \\
0.20 \pm 0.03 \mu \mathrm{M} \text { for KKU-055, } \\
0.12 \pm 0.02 \mu \mathrm{M} \text { for KKU-213 cells, } \\
\text { and } 0.25 \pm 0.04 \mu \mathrm{M} \text { for KKU-100. } \\
\mathrm{IC}_{50} \text { values for cell growth } \\
\text { inhibition on day } 1 \text { for KKU-055 } \\
\text { cells, KKU-213, KKU-100, } \\
\text { respectively, } 31.95 \pm 1.15 \mu \mathrm{M}, \\
32.95 \pm 1.16 \mu \mathrm{M}, 48.74 \pm 1.22 \mu \mathrm{M}, \\
\text { and for the day } 3 \text { were } \\
5.78 \pm 1.15 \mu \mathrm{M}, 2.47 \pm 1.19 \mu \mathrm{M}, \\
3.00 \pm 1.28 \mu \mathrm{M} .\end{array}$ \\
\hline Oral [50] & YD-38 and NHOKs & $\begin{array}{l}\text { YD-38 cells express LAT1 but do } \\
\text { not express LAT2. NHOKs cells } \\
\text { express LAT1 and LAT2, with } \\
\text { very weak LAT1 expression. }\end{array}$ & $\begin{array}{l}\text { Inhibit L-leucine in YD- } 38 \text { cells } \\
\left(\mathrm{IC}_{50} \text { value: } 0.79 \mu \mathrm{M}\right) \text { and NHOK } \\
\left(\mathrm{IC}_{50} \text { value: }>100 \mu \mathrm{M}\right) \text {. However, } \\
\text { it is not enough to suppress the } \\
\text { growth of YD-38 cells }\left(\mathrm{IC}_{50} \text { value: }\right. \\
69 \mu \mathrm{M}) \text {. }\end{array}$ \\
\hline
\end{tabular}

Table 2. In vivo studies.

\begin{tabular}{|c|c|c|c|}
\hline Cancer Type [Ref] & Tumor Model & LAT1 Expression & JPH203 Activities \\
\hline Anaplastic Thyroid [51] & $\begin{array}{l}\text { Mice xenograft of } 8505 \mathrm{C} \text { cell } \\
\text { line with BRAF, PI3K3R1/2, } \\
\text { and p53 mutations. }\end{array}$ & $\begin{array}{l}\text { Excessive expression of LAT1 } \\
\text { in human ATC ( } 78 \%: 11 / 14 \\
\text { cases of ATC) }\end{array}$ & $\begin{array}{l}\text { Reduce the growth ratio of } \\
\text { xenograft tumors and also } \\
\text { reduce tumor size. }\end{array}$ \\
\hline $\begin{array}{l}\text { Biliary duct } \\
\text { (cholangiocarcinoma) [56] }\end{array}$ & KKA-213 CCA cell xenograft & - & $\begin{array}{l}\text { On days } 18 \text { and } 21, \mathrm{JPH} 203 \\
\text { inhibited dose-related tumor } \\
\text { growth in the JPH203 group } \\
12.5 \mathrm{mg} / \mathrm{kg} \text { (on day } 18, \\
p<0.05 \text {, day } 21, p<0.01 \text { ) and } \\
25 \mathrm{mg} / \mathrm{kg} \text { (on days } 18 \text { and } 21 \text {, } \\
p<0.001 \text { ) compared to the } \\
\text { control group. }\end{array}$ \\
\hline Colorectal [47] & HT-29 cell xenograft & - & $\begin{array}{l}\text { Inhibit }{ }^{14} \mathrm{C} \text {-leucine absorption } \\
\text { and cell growth }\left(\mathrm{IC}_{50} 0.14 \mu \mathrm{M}\right. \\
\text { and } 16.4 \mu \mathrm{M}) \text {. }\end{array}$ \\
\hline
\end{tabular}

\subsection{Gastric and Colorectal Cancer}

LAT1 was overexpressed on all stomach and colorectal cancer cell lines tested, and JPH203 significantly suppressed the growth of these cells. In a previous study (2010) on HT-29 colorectal cancer cells, JPH203 was able to inhibit the uptake of ${ }^{14} \mathrm{C}$-leucine and the growth of cancer cells with $\mathrm{IC}_{50} 0.06 \mu \mathrm{M}$ and $4.1 \mu \mathrm{M}$, respectively [47]. In this study, JPH203 suppressed the growth of the LoVo colorectal cancer cell line with $\mathrm{IC}_{50} 2.3 \pm 0.3 \mu \mathrm{M}$ 
and $30.0 \pm 6.4 \mu \mathrm{M}$ on HT-29 cells. Meanwhile, JPH203 suppressed the growth of gastric cancer cells with $\mathrm{IC}_{50} 41.7 \pm 2.3 \mu \mathrm{M}$ on MKN1 cells and $4.6 \pm 1.0 \mu \mathrm{M}$ on MKN45 cells [51].

\subsection{Anaplastic Thyroid Cancer}

A new therapeutic approach for anaplastic thyroid cancer (ATC) cases is highly anticipated due to its progressive nature and resistance against ${ }^{131}$ I radionuclide therapy, unlike well-differentiated thyroid cancer. Human ATC expresses LAT1 in the majority of cases (78\%: 11/14 cases). It was recently reported that ATC expresses the MYC protein and MYC inhibition by its selective inhibitor, JQ1, suppressing ATC growth and increasing survival in preclinical models. Since the MYC gene is involved in LAT1 overexpression, direct inhibition of LAT1 would achieve a similar anti-tumor effect. In this study, JPH203 significantly inhibits the proliferation of three types of ATC cells (8505C, OCUT-2, and OCUT-6) via suppression of mTOR signaling and inhibits the cell cycle from the G0/G1 phase to the S phase. Growth decline and shrinking tumor size by JPH203 through inhibition of mTOR and G0/G1 cell cycle-related proteins are also confirmed in animal tumor models. These preclinical findings indicate that JPH203 is a strong candidate for ATC therapy given that the current therapeutic choice for ATC is very limited. More importantly, it was shown from an in vitro and animal study that JPH203 also has therapeutic potential for papillary thyroid carcinoma, the most common thyroid cancer [51].

\subsection{Osteosarcoma}

The JPH203 effects on bone cancer have been investigated on LAT1 and LAT2expressing osteoblastic FOB cells and Saos2 human osteosarcoma. JPH203 inhibited Lleucine uptake by Saos2 cells and induced apoptosis. This study showed that JPH203 activated mitochondrial-dependent apoptotic signaling via increased pro-apoptotic factors, such as Bad, Bax, and Bak, and the active form of caspase-9, and decreased anti-apoptotic factors, such as Bcl-2 and Bcl-xL. These results indicated that the LAT1 inhibition by JPH203induced apoptosis was obtained through the mediation of mitochondrial-dependent intrinsic apoptotic signaling by reducing intracellular neutral amino acid supplies that are essential for growth [55].

\subsection{Medulloblastoma}

Medulloblastoma is classified into four genetic and clinically relevant subtypes: Wnt, Shh, subgroup 3, and subgroup 4. JPH203 activity was investigated on cell lines representing two subtypes; HD-MB03 (for subgroup 3) and DAOY (for Shh). The results show that JPH203 interferes with amino acid homeostasis and mTOR complex activity in medulloblastoma cells, thus inhibiting proliferation and suppressing its growth. More importantly, it was observed that JPH203 toxicity toward normal brain cells was low, and long-term JPH203 therapy on medulloblastoma cells did not trigger resistance [53].

\subsection{Renal Cell Carcinoma}

Immunohistochemical studies show that LAT1 is expressed in the majority $(92 \%)$ of renal cancer tissue examined. Therapeutic studies on the Caki-1 cells and ACHN (kidney cell carcinoma derivatives) showed that JPH203 inhibits growth in a dose-dependent fashion. Moreover, JPH203 significantly suppresses the migration and invasion of renal cell carcinoma. Clinical observation in this study indicates that LAT1 does not only have great potential as a prognostic biomarker of renal cell carcinoma but also as a target of clinical therapy [27].

\subsection{Bladder Carcinoma}

LAT1 expression was significantly higher in bladder cancer cells compared with normal cells $(p=0.0051)$. LAT1 inhibition by JPH203 was observed in two bladder cancer cell lines with the highest and the second-highest LAT1 expression, namely T24 and 5637 cells. In this study, it was also observed that insulin-like growth factor-binding 
protein 5 (IGFBP-5) is a downstream target of LAT1 inhibition by JPH203. Phase II clinical trials are currently being prepared in urological cancer (including bladder cancer) based on these findings [57].

\subsection{Biliary Duct Cancer}

Both in vitro and in vivo JPH203 investigations in cholangiocarcinoma cells showed that JPH203 suppressed its growth and its ${ }^{14} \mathrm{C}$-leucine uptake. Besides, JPH203 also induced termination of the G2/M and G0/G1 cell cycles and shortened the S phase with changes in expression of cell cycle progression proteins (cyclin D1, CDK4, and CDK6). In a mouse xenograft tumor model of the KKU-213 cholangiocarcinoma cell, daily intravenous administration of JPH203 (12.5 and $25 \mathrm{mg} / \mathrm{kg}$ doses) significantly inhibits tumor growth in a dose-dependent manner, without significant body weight changes and any histological differences and appearance of internal organs compared to the control group. This study shows that the inhibition of LAT1 by JPH203 may become a potential therapeutic strategy for cholangiocarcinoma $[56,58]$.

\section{JPH203 in Phase I Clinical Trial}

Therapeutic options for postoperative biliary duct cancer (cholangiocarcinoma) patients are limited; thus, their 5-year survival remains poor (33\% in 2008 and 39.8\% in 2013) [29]. This poor prognosis corresponds to increased LAT1 expression in up to $64 \%$ biliary duct cancer cases [33,59], similar or higher than other malignancies such as triplenegative breast cancer (64\%) [25], pancreatic cancer (52.6\%) [32], stomach cancer (43\%) [37], lung adenocarcinoma (29\%) [31], and prostate cancer (22\%) [60]. Preclinical studies have shown that LAT1 inhibition and JPH203 are effective for cholangiocarcinoma $[56,58,61]$.

In January 2018, Okano et al. presented their first in-human study result of JPH203 therapy on several types of solid tumors at the Gastrointestinal Cancers Symposium (American Society of Clinical Oncology). In May 2020, Okano et al. reported their phase I clinical trial result. This study evaluates JPH203 toxicity in an escalating dose, open-label, $3+3$ design involving 17 advanced solid tumor patients with their primary tumors in the colorectal $(n=6)$, bile ducts $(n=5)$, pancreas $(n=4)$, esophagus $(n=1)$, and breast $(n=1)$. A promising efficacy was observed on bile duct cancer patients ( 2 patients; 1 stable disease, 1 partial response), despite the limited number of patients. All patients received intravenous JPH203 infusion for 90 min every day for seven days, which was then followed by a 21-day rest period. The JPH203 infusion solution contains JPH203 in a sulfobutyl-ether$\beta$-cyclodextrin complex to increase solubility. The escalating dose plan was $12 \mathrm{mg} / \mathrm{m}^{2}$, $25 \mathrm{mg} / \mathrm{m}^{2}, 40 \mathrm{mg} / \mathrm{m}^{2}, 60 \mathrm{mg} / \mathrm{m}^{2}$, and $85 \mathrm{mg} / \mathrm{m}^{2}$. Initial doses were determined from toxicology studies in animals (mice) which showed no significant side effects at a $2 \mathrm{mg} / \mathrm{kg}$ dose (equivalent to a $12 \mathrm{mg} / \mathrm{m}^{2}$ human dose) [13].

JPH203 was well tolerated with a sufficient safety margin between the maximum tolerated dose (MTD) of $60 \mathrm{mg} / \mathrm{m}^{2}$. Despite the MTD being set at $60 \mathrm{mg} / \mathrm{m}^{2}$, the pharmacokinetic profile does not support the recommended dosage for phase II (RP2D) at doses $>25 \mathrm{mg} / \mathrm{m}^{2}$. The most severe side effect observed was a third-degree hepatic injury in the form of elevated levels of ALT, AST, or $\gamma$-GTP, starting at $40 \mathrm{mg} / \mathrm{m}^{2}$ dose. Thus, a $25 \mathrm{mg} / \mathrm{m}^{2}$ dose is recommended as RP2D, with the presumption that a high dose JPH203 administration has a negative feedback on the LAT1 pathway $[56,58]$.

Since JPH203 is metabolized to Nac-JPH203, its plasma concentration should depend on liver enzyme activity. Depending on NAT2 expression, three acetylator phenotypes do exist: rapid, intermediate, and slow. In patients with a rapid NAT2 phenotype, the ratio of Nac-JPH203 is higher, indicating that Nac-JPH203 is formed more quickly. In an Okano et al. study, severe adverse effects of liver function occurred in the rapid NAT2 phenotype patients [13]. Therefore, a thorough evaluation in this regard is important to minimize the risk of liver damage in subsequent studies. A placebo-controlled, phase II randomized clinical trial of JPH203 in bile duct cancer patients is currently being prepared. 


\section{Insights for Radiotheranostic Purpose}

Considering several points from the recent findings above, e.g., (1) LAT1 inhibitionderived JPH203 therapeutic efficacies in a wide range of cancer types, (2) lack of LAT1 distribution in normal tissues and other pathologies (in particular, inflammations), and (3) well-tolerated clinical safety profile, it might be safe to speculate that JPH203 can be a model of an efficient and safe pan-cancer targeted drug design. Given the strictly localized LAT1 expression on tumors, LAT1 expression on the cancer cell membrane, and the recent insights on the LAT1 inhibition process, JPH203 might also have the potential to be further elaborated as radiotheranostic agents. Since a radiotheranostic approach counts heavily on radionuclide irradiation strength, only a trace mass of JPH203 would be required as vehicles to deliver this radiation straight into tumors [62]. In such a strategy, hepatotoxicity potential would be irrelevant. Modifications with bifunctional chelators (to allow labeling with radiotheranostic pairs of radiometals) might be safely made on position E (Figure 4); however, comprehensive molecular docking studies and synthetic experiments are required to ensure its inhibitory potency and validate such design.

\section{Conclusions}

JPH203 is the most potent LAT1-selective non-transportable inhibitor available today and has demonstrated an excellent $\mathrm{IC}_{50}$ value in suppressing tumor growth in pre-clinical evaluation in various types of cancer. The clinical translation of JPH203 is imminent.

Author Contributions: Conceptualization, data collection, A.A. and H.A.H.; data collection and writing-original draft, S.L.; validation, A.A., H.A.H., D.R. and M.H.B.; writing-review and editing, A.A.; visualization, A.A.; supervision, H.A.H., D.R., M.H.B., A.F. and A.H.S.K.; funding acquisition, A.H.S.K. All authors have read and agreed to the published version of the manuscript.

Funding: This research was supported by an Academic Leadership Grant on behalf of A.H.S.K. from the Directorate of Research, Community Service, and Innovation of Universitas Padjadjaran (no. 1427/UN6.3.1/LT/2020).

Institutional Review Board Statement: Not applicable.

Informed Consent Statement: Not applicable.

Data Availability Statement: No new data were created or analyzed in this study. Data sharing is not applicable.

Conflicts of Interest: The authors declare no conflict of interest.

\section{References}

1. Bray, F.; Ferlay, J.; Soerjomataram, I.; Siegel, R.L.; Torre, L.A.; Jemal, A. Global cancer statistics 2018: GLOBOCAN estimates of incidence and mortality worldwide for 36 cancers in 185 countries. CA Cancer J. Clin. 2018, 68, 394-424. [CrossRef] [PubMed]

2. Fitzmaurice, C.; Abate, D.; Abbasi, N.; Abbastabar, H.; Abd-Allah, F.; Abdel-Rahman, O.; Abdelalim, A.; Abdoli, A.; Abdollahpour, I.; Abdulle, A.S. Global, regional, and national cancer incidence, mortality, years of life lost, years lived with disability, and disability-adjusted life-years for 29 cancer groups, 1990 to 2017: A systematic analysis for the global burden of disease study. JAMA Oncol. 2019, 5, 1749-1768. [PubMed]

3. Hanahan, D.; Weinberg, R.A. Hallmarks of Cancer: The Next Generation. Cell 2011, 144, 646-674. [CrossRef]

4. Chabner, B.A.; Roberts, T.G. Chemotherapy and the war on cancer. Nat. Rev. Cancer 2005, 5, 65-72. [CrossRef] [PubMed]

5. Schirrmacher, V. From chemotherapy to biological therapy: A review of novel concepts to reduce the side effects of systemic cancer treatment. Int. J. Oncol. 2019, 54, 407-419. [PubMed]

6. Lee, Y.T.; Tan, Y.J.; Oon, C.E. Molecular targeted therapy: Treating cancer with specificity. Eur. J. Pharmacol. 2018, 834, 188-196. [CrossRef] [PubMed]

7. Falzone, L.; Salomone, S.; Libra, M. Evolution of Cancer Pharmacological Treatments at the Turn of the Third Millennium. Front. Pharmacol. 2018, 9, 1300. [CrossRef]

8. Martinez-Outschoorn, U.E.; Peiris-Pages, M.; Pestell, R.G.; Sotgia, F.; Lisanti, M.P. Cancer metabolism: A therapeutic perspective. Nat. Rev. Clin. Oncol. 2017, 14, 11. [CrossRef]

9. Wei, Z.; Liu, X.; Cheng, C.; Yu, W.; Yi, P. Metabolism of Amino Acids in Cancer. Front. Cell Dev. Biol. 2020, 8, 1628.

10. Scalise, M.; Console, L.; Rovella, F.; Galluccio, M.; Pochini, L.; Indiveri, C. Membrane Transporters for Amino Acids as Players of Cancer Metabolic Rewiring. Cells 2020, 9, 2028. [CrossRef] 
11. Häfliger, P.; Charles, R.-P. The L-Type Amino Acid Transporter LAT1-An Emerging Target in Cancer. Int. J. Mol. Sci. 2019, 20, 2428. [CrossRef]

12. Lopes, C.; Pereira, C.; Medeiros, R. ASCT2 and LAT1 Contribution to the Hallmarks of Cancer: From a Molecular Perspective to Clinical Translation. Cancers 2021, 13, 203. [CrossRef]

13. Okano, N.; Naruge, D.; Kawai, K.; Kobayashi, T.; Nagashima, F.; Endou, H.; Furuse, J. First-in-human phase I study of JPH203, an L-type amino acid transporter 1 inhibitor, in patients with advanced solid tumors. Investig. New Drugs 2020, 38, 1495-1506. [CrossRef] [PubMed]

14. Chen, W.; Sun, Z.; Lu, L. Targeted Engineering of Medicinal Chemistry for Cancer Therapy: Recent Advances and Perspectives. Angew. Chem. Int. Ed. 2021, 60, 5626-5643. [CrossRef] [PubMed]

15. Miller, J.F.A.P.; Sadelain, M. The Journey from Discoveries in Fundamental Immunology to Cancer Immunotherapy. Cancer Cell 2015, 27, 439-449. [CrossRef]

16. Sharma, P.; Hu-Lieskovan, S.; Wargo, J.A.; Ribas, A. Primary, Adaptive, and Acquired Resistance to Cancer Immunotherapy. Cell 2017, 168, 707-723. [CrossRef] [PubMed]

17. Boumahdi, S.; de Sauvage, F.J. The great escape: Tumour cell plasticity in resistance to targeted therapy. Nat. Rev. Drug Discov. 2020, 19, 39-56. [CrossRef]

18. Pavlova, N.N.; Thompson, C.B. The Emerging Hallmarks of Cancer Metabolism. Cell Metab. 2016, 23, 27-47. [CrossRef]

19. Kandasamy, P.; Gyimesi, G.; Kanai, Y.; Hediger, M.A. Amino acid transporters revisited: New views in health and disease. Trends Biochem. Sci. 2018, 43, 752-789. [CrossRef]

20. Hosios, A.M.; Hecht, V.C.; Danai, L.V.; Johnson, M.O.; Rathmell, J.C.; Steinhauser, M.L.; Manalis, S.R.; Vander Heiden, M.G. Amino Acids Rather than Glucose Account for the Majority of Cell Mass in Proliferating Mammalian Cells. Dev. Cell 2016, 36, 540-549. [CrossRef]

21. Scalise, M.; Galluccio, M.; Console, L.; Pochini, L.; Indiveri, C. The Human SLC7A5 (LAT1): The Intriguing Histidine/Large Neutral Amino Acid Transporter and Its Relevance to Human Health. Front. Chem. 2018, 6, 243. [CrossRef] [PubMed]

22. Bhutia, Y.D.; Babu, E.; Ramachandran, S.; Ganapathy, V. Amino acid transporters in cancer and their relevance to "glutamine addiction": Novel targets for the design of a new class of anticancer drugs. Cancer Res. 2015, 75, 1782-1788. [CrossRef] [PubMed]

23. Singh, N.; Ecker, G.F. Insights into the structure, function, and ligand discovery of the large neutral amino acid transporter 1 , LAT1. Int. J. Mol. Sci. 2018, 19, 1278. [CrossRef]

24. Yan, R.; Zhao, X.; Lei, J.; Zhou, Q. Structure of the human LAT1-4F2hc heteromeric amino acid transporter complex. Nature 2019, 568, 127-130. [CrossRef]

25. Furuya, M.; Horiguchi, J.; Nakajima, H.; Kanai, Y.; Oyama, T. Correlation of L-type amino acid transporter 1 and CD98 expression with triple negative breast cancer prognosis. Cancer Sci. 2012, 103, 382-389. [CrossRef] [PubMed]

26. Haining, Z.; Kawai, N.; Miyake, K.; Okada, M.; Okubo, S.; Zhang, X.; Fei, Z.; Tamiya, T. Relation of LAT1/4F2hc expression with pathological grade, proliferation and angiogenesis in human gliomas. BMC Clin. Pathol. 2012, 12, 4. [CrossRef] [PubMed]

27. Higuchi, K.; Sakamoto, S.; Ando, K.; Maimaiti, M.; Takeshita, N.; Okunushi, K.; Reien, Y.; Imamura, Y.; Sazuka, T.; Nakamura, K. Characterization of the expression of LAT1 as a prognostic indicator and a therapeutic target in renal cell carcinoma. Sci. Rep. 2019, 9, 1-10. [CrossRef]

28. Honjo, H.; Kaira, K.; Miyazaki, T.; Yokobori, T.; Kanai, Y.; Nagamori, S.; Oyama, T.; Asao, T.; Kuwano, H. Clinicopathological significance of LAT1 and ASCT2 in patients with surgically resected esophageal squamous cell carcinoma. J. Surg. Oncol. 2016, 113, 381-389. [CrossRef] [PubMed]

29. Ishihara, S.; Horiguchi, A.; Miyakawa, S.; Endo, I.; Miyazaki, M.; Takada, T. Biliary tract cancer registry in Japan from 2008 to 2013. J. Hepatobiliary Pancreat. Sci. 2016, 23, 149-157. [CrossRef]

30. Kaira, K.; Nakamura, K.; Hirakawa, T.; Imai, H.; Tominaga, H.; Oriuchi, N.; Nagamori, S.; Kanai, Y.; Tsukamoto, N.; Oyama, T.; et al. Prognostic significance of L-type amino acid transporter 1 (LAT1) expression in patients with ovarian tumors. Am. J. Transl. Res. 2015, 7, 1161-1171.

31. Kaira, K.; Oriuchi, N.; Imai, H.; Shimizu, K.; Yanagitani, N.; Sunaga, N.; Hisada, T.; Ishizuka, T.; Kanai, Y.; Nakajima, T. Prognostic significance of L-type amino acid transporter 1 (LAT1) and 4F2 heavy chain (CD98) expression in stage I pulmonary adenocarcinoma. Lung Cancer 2009, 66, 120-126. [CrossRef]

32. Kaira, K.; Sunose, Y.; Arakawa, K.; Ogawa, T.; Sunaga, N.; Shimizu, K.; Tominaga, H.; Oriuchi, N.; Itoh, H.; Nagamori, S.; et al. Prognostic significance of L-type amino-acid transporter 1 expression in surgically resected pancreatic cancer. Br. J. Cancer 2012, 107, 632-638. [CrossRef]

33. Kaira, K.; Sunose, Y.; Ohshima, Y.; Ishioka, N.S.; Arakawa, K.; Ogawa, T.; Sunaga, N.; Shimizu, K.; Tominaga, H.; Oriuchi, N. Clinical significance of L-type amino acid transporter 1 expression as a prognostic marker and potential of new targeting therapy in biliary tract cancer. BMC Cancer 2013, 13, 482. [CrossRef]

34. Namikawa, M.; Kakizaki, S.; Kaira, K.; Tojima, H.; Yamazaki, Y.; Horiguchi, N.; Sato, K.; Oriuchi, N.; Tominaga, H.; Sunose, Y. Expression of amino acid transporters (LAT1, ASCT2 and xCT) as clinical significance in hepatocellular carcinoma. Hepatol. Res. 2015, 45, 1014-1022. [CrossRef] [PubMed]

35. Nikkuni, O.; Kaira, K.; Toyoda, M.; Shino, M.; Sakakura, K.; Takahashi, K.; Tominaga, H.; Oriuchi, N.; Suzuki, M.; Iijima, M.; et al. Expression of Amino Acid Transporters (LAT1 and ASCT2) in Patients with Stage III/IV Laryngeal Squamous Cell Carcinoma. Pathol. Oncol. Res. 2015, 21, 1175-1181. [CrossRef] [PubMed] 
36. Toyoda, M.; Kaira, K.; Ohshima, Y.; Ishioka, N.S.; Shino, M.; Sakakura, K.; Takayasu, Y.; Takahashi, K.; Tominaga, H.; Oriuchi, N.; et al. Prognostic significance of amino-acid transporter expression (LAT1, ASCT2, and xCT) in surgically resected tongue cancer. Br. J. Cancer 2014, 110, 2506-2513. [CrossRef] [PubMed]

37. Ichinoe, M.; Mikami, T.; Yoshida, T.; Igawa, I.; Tsuruta, T.; Nakada, N.; Anzai, N.; Suzuki, Y.; Endou, H.; Okayasu, I. High expression of L-type amino-acid transporter 1 (LAT1) in gastric carcinomas: Comparison with non-cancerous lesions. Pathol. Int. 2011, 61, 281-289. [CrossRef] [PubMed]

38. Achmad, A.; Bhattarai, A.; Yudistiro, R.; Heryanto, Y.D.; Higuchi, T.; Tsushima, Y. The diagnostic performance of ${ }^{18}$ F-FAMT PET and ${ }^{18}$ F-FDG PET for malignancy detection: A meta-analysis. BMC Med. Imaging 2017, 17, 66. [CrossRef]

39. Kim, M.; Achmad, A.; Higuchi, T.; Arisaka, Y.; Yokoo, H.; Yokoo, S.; Tsushima, Y. Effects of intratumoral inflammatory process on ${ }^{18}$ F-FDG uptake: Pathologic and comparative study with ${ }^{18}$ F-fluoro-alpha-methyltyrosine PET/CT in oral squamous cell carcinoma. J. Nucl. Med. 2015, 56, 16-21. [CrossRef]

40. Wei, L.; Tominaga, H.; Ohgaki, R.; Wiriyasermkul, P.; Hagiwara, K.; Okuda, S.; Kaira, K.; Oriuchi, N.; Nagamori, S.; Kanai, Y. Specific transport of 3-fluoro-l-alpha-methyl-tyrosine by LAT1 explains its specificity to malignant tumors in imaging. Cancer Sci. 2016, 107, 347-352. [CrossRef] [PubMed]

41. Wempe, M.F.; Rice, P.J.; Lightner, J.W.; Jutabha, P.; Hayashi, M.; Anzai, N.; Wakui, S.; Kusuhara, H.; Sugiyama, Y.; Endou, H. Metabolism and pharmacokinetic studies of JPH203, an L-amino acid transporter 1 (LAT1) selective compound. Drug Metab. Pharmacokinet. 2012, 27, 155-161. [CrossRef] [PubMed]

42. Endou, H.; Kanai, Y.; Tsujihara, K.; Saito, K. Aromatic Amino Acid Derivatives and Medicinal Compositions. U.S. Patent 7345086B2, 3 March 2008.

43. Kongpracha, P.; Nagamori, S.; Wiriyasermkul, P.; Tanaka, Y.; Kaneda, K.; Okuda, S.; Ohgaki, R.; Kanai, Y. Structure-activity relationship of a novel series of inhibitors for cancer type transporter L-type amino acid transporter 1 (LAT1). J. Pharmacol. Sci. 2017, 133, 96-102. [CrossRef] [PubMed]

44. Singh, N.; Villoutreix, B.O.; Ecker, G.F. Rigorous sampling of docking poses unveils binding hypothesis for the halogenated ligands of L-type Amino acid Transporter 1 (LAT1). Sci. Rep. 2019, 9, 15061. [CrossRef] [PubMed]

45. Uchino, H.; Kanai, Y.; Kim, D.K.; Wempe, M.F.; Chairoungdua, A.; Morimoto, E.; Anders, M.; Endou, H. Transport of amino acidrelated compounds mediated by L-type amino acid transporter 1 (LAT1): Insights into the mechanisms of substrate recognition. Mol. Pharmacol. 2002, 61, 729-737. [CrossRef] [PubMed]

46. Wempe, M.F.; Jutabha, P.; Kumar, V.; Fisher, J.A.; Waers, K.; Holt, M.D.; Dodson, A.M.; Bautista, J.; Gehr, D.T.; Backos, D.S. Developing selective L-Amino Acid Transport 1 (LAT1) inhibitors: A structure-activity relationship overview. Med. Res. Arch. 2019, 7. [CrossRef]

47. Oda, K.; Hosoda, N.; Endo, H.; Saito, K.; Tsujihara, K.; Yamamura, M.; Sakata, T.; Anzai, N.; Wempe, M.F.; Kanai, Y.; et al. L-type amino acid transporter 1 inhibitors inhibit tumor cell growth. Cancer Sci. 2010, 101, 173-179. [CrossRef]

48. Okanishi, H.; Ohgaki, R.; Okuda, S.; Endou, H.; Kanai, Y. Proteomics and phosphoproteomics reveal key regulators associated with cytostatic effect of amino acid transporter LAT1 inhibitor. Cancer Sci. 2021, 112, 871-883. [CrossRef]

49. Singh, N.; Scalise, M.; Galluccio, M.; Wieder, M.; Seidel, T.; Langer, T.; Indiveri, C.; Ecker, G.F. Discovery of potent inhibitors for the large neutral amino acid transporter 1 (LAT1) by structure-based methods. Int. J. Mol. Sci. 2019, 20, 27. [CrossRef]

50. Yun, D.-W.; Lee, S.A.; Park, M.-G.; Kim, J.-S.; Yu, S.-K.; Park, M.-R.; Kim, S.-G.; Oh, J.-S.; Kim, C.S.; Kim, H.-J. JPH203, an L-type amino acid transporter 1-selective compound, induces apoptosis of YD-38 human Oral Cancer cells. J. Pharmacol. Sci. 2014, 13154FP. [CrossRef]

51. Enomoto, K.; Sato, F.; Tamagawa, S.; Gunduz, M.; Onoda, N.; Uchino, S.; Muragaki, Y.; Hotomi, M. A novel therapeutic approach for anaplastic thyroid cancer through inhibition of LAT1. Sci. Rep. 2019, 9, 1-11. [CrossRef]

52. Hafliger, P.; Graff, J.; Rubin, M.; Stooss, A.; Dettmer, M.S.; Altmann, K.H.; Gertsch, J.; Charles, R.P. The LAT1 inhibitor JPH203 reduces growth of thyroid carcinoma in a fully immunocompetent mouse model. J. Exp. Clin. Cancer Res. 2018, 37, 234. [CrossRef]

53. Cormerais, Y.; Pagnuzzi-Boncompagni, M.; Schrotter, S.; Giuliano, S.; Tambutte, E.; Endou, H.; Wempe, M.F.; Pages, G.; Pouyssegur, J.; Picco, V. Inhibition of the amino-acid transporter LAT1 demonstrates anti-neoplastic activity in medulloblastoma. J. Cell Mol. Med. 2019, 23, 2711-2718. [CrossRef] [PubMed]

54. Muto, Y.; Furihata, T.; Kaneko, M.; Higuchi, K.; Okunushi, K.; Morio, H.; Reien, Y.; Uesato, M.; Matsubara, H.; Anzai, N. Different Response Profiles of Gastrointestinal Cancer Cells to an L-Type Amino Acid Transporter Inhibitor, JPH203. Anticancer Res. 2019, 39, 159-165. [CrossRef] [PubMed]

55. Choi, D.W.; Kim, D.K.; Kanai, Y.; Wempe, M.F.; Endou, H.; Kim, J.K. JPH203, a selective L-type amino acid transporter 1 inhibitor, induces mitochondria-dependent apoptosis in Saos2 human osteosarcoma cells. Korean J. Physiol. Pharmacol. $2017,21,599-607$. [CrossRef]

56. Yothaisong, S.; Dokduang, H.; Anzai, N.; Hayashi, K.; Namwat, N.; Yongvanit, P.; Sangkhamanon, S.; Jutabha, P.; Endou, H.; Loilome, W. Inhibition of l-type amino acid transporter 1 activity as a new therapeutic target for cholangiocarcinoma treatment. Tumor Biol. 2017, 39, 1010428317694545. [CrossRef]

57. Maimaiti, M.; Sakamoto, S.; Yamada, Y.; Sugiura, M.; Rii, J.; Takeuchi, N.; Imamura, Y.; Furihata, T.; Ando, K.; Higuchi, K. Expression of L-type amino acid transporter 1 as a molecular target for prognostic and therapeutic indicators in bladder carcinoma. Sci. Rep. 2020, 10, 1-14. [CrossRef] 
58. Yothaisong, S.; Namwat, N.; Yongvanit, P.; Khuntikeo, N.; Puapairoj, A.; Jutabha, P.; Anzai, N.; Tassaneeyakul, W.; Tangsucharit, P.; Loilome, W. Increase in L-type amino acid transporter 1 expression during cholangiocarcinogenesis caused by liver fluke infection and its prognostic significance. Parasitol. Int. 2017, 66, 471-478. [CrossRef]

59. Yanagisawa, N.; Hana, K.; Nakada, N.; Ichinoe, M.; Koizumi, W.; Endou, H.; Okayasu, I.; Murakumo, Y. High expression of L-type amino acid transporter 1 as a prognostic marker in bile duct adenocarcinomas. Cancer Med. 2014, 3, 1246-1255. [CrossRef] [PubMed]

60. Sakata, T.; Ferdous, G.; Tsuruta, T.; Satoh, T.; Baba, S.; Muto, T.; Ueno, A.; Kanai, Y.; Endou, H.; Okayasu, I. L-type amino-acid transporter 1 as a novel biomarker for high-grade malignancy in prostate cancer. Pathol. Int. 2009, 59, 7-18. [CrossRef]

61. Janpipatkul, K.; Suksen, K.; Borwornpinyo, S.; Jearawiriyapaisarn, N.; Hongeng, S.; Piyachaturawat, P.; Chairoungdua, A. Downregulation of LAT1 expression suppresses cholangiocarcinoma cell invasion and migration. Cell Signal. 2014, 26, 1668-1679. [CrossRef] [PubMed]

62. Mikulová, M.B.; Mikuš, P. Advances in Development of Radiometal Labeled Amino Acid-Based Compounds for Cancer Imaging and Diagnostics. Pharmaceuticals 2021, 14, 167. [CrossRef] [PubMed] 